\title{
Generic status of Winitia (Annonaceae, Miliuseae) reaffirmed by molecular phylogenetic analysis, including a new species and a new combination from Thailand
}

\author{
Tanawat CHAOWASKU ${ }^{1, *}$, Kithisak AONGYONG ${ }^{2}$, Anissara DAMTHONGDEE ${ }^{3}$, \\ Hathaichanok JONGSOOK ${ }^{4} \&$ David M. JOHNSON ${ }^{5}$ \\ ${ }_{1,3,4}$ Herbarium, Division of Plant Science and Technology, Faculty of Science, Chiang Mai University, \\ 239 Huay Kaew Rd., Chiang Mai 50200, Thailand. \\ ${ }^{1}$ Research Center in Bioresources for Agriculture, Industry, and Medicine, Chiang Mai University, \\ 239 Huay Kaew Rd., Chiang Mai 50200, Thailand. \\ ${ }^{2}$ Sichon, Nakhon Si Thammarat 80120, Thailand. \\ ${ }^{5}$ Department of Botany and Microbiology, Ohio Wesleyan University, Delaware, Ohio 43015, USA. \\ *Corresponding author: tanawat.chaowasku@cmu.ac.th \\ 22Email: siamocananga@hotmail.com \\ ${ }^{3}$ Email: aniss.damthongdee@gmail.com \\ ${ }^{4}$ Email: hathaichanok_j@outlook.com \\ ${ }^{5}$ Email: dmjohnso@owu.edu
}

\begin{abstract}
The generic status of Winitia Chaowasku (Annonaceae Juss., Miliuseae Hook.f. \& Thomson) is reaffirmed by an extensive phylogenetic reconstruction using seven plastome regions $(m a t \mathrm{~K}, n d h \mathrm{~F}$, $r b c \mathrm{~L}, y c f 1$ exons; $\operatorname{trn} \mathrm{L}$ intron; $p s b \mathrm{~A}-t r n \mathrm{H}, \operatorname{tr} n \mathrm{~L}-\operatorname{trn} \mathrm{F}$ intergenic spacers) and including, among others, seven accessions of Winitia plus two accessions of its sister group, Stelechocarpus Hook.f. \& Thomson. The results disclosed a maximally supported clade of Winitia, as well as of Stelechocarpus. The sister relationship of the two genera is still rather poorly supported and the branch uniting them is very short, whereas the branches leading to Winitia and to Stelechocarpus are relatively long, corresponding to their considerable morphological differences. Additionally, in Miliuseae there is a particular indel of eight continuous base pairs in the $\operatorname{trn} \mathrm{L}-\operatorname{trn} \mathrm{F}$ intergenic spacer potentially diagnostic for generic discrimination, i.e., members in the same genus possess the same indel structure (absence or presence of a gap), and this indel differentiates Winitia from Stelechocarpus. Winitia cauliflora (Scheff.) Chaowasku appears polyphyletic and Winitia longipes (Craib) Chaowasku \& Aongyong comb. nov. based on Stelechocarpus longipes Craib is consequently proposed. Furthermore, our phylogenetic data support a new species, Winitia thailandana Chaowasku \& Aongyong sp. nov. from southern Thailand, which is described and illustrated. A key to genera in the sageraeoid clade (Sageraea-Winitia-Stelechocarpus) and a key to the four species of Winitia are provided.
\end{abstract}

Keywords. Identification key, Malmeoideae, phylogenetics, systematics, taxonomy.

Chaowasku T., Aongyong K., Damthongdee A., Jongsook H. \& Johnson D.M. 2020. Generic status of Winitia (Annonaceae, Miliuseae) reaffirmed by molecular phylogenetic analysis, including a new species and a new combination from Thailand. European Journal of Taxonomy 659: 1-23. https://doi.org/10.5852/ejt.2020.659 


\section{Introduction}

Annonaceae Juss. are a large pantropical family of flowering plants prominent in lowland rainforests and consisting of ca 2430 species (Couvreur et al. 2019) in 110 genera (Guo et al. 2017b; Chaowasku et al. 2018a, 2018b; Xue et al. 2018). Infrafamilial classifications and generic realignments of the family have been stabilized lately with the help of molecular phylogenetics (e.g., Zhou et al. 2009, 2010; Chatrou et al. 2012; Chaowasku et al. 2012; Xue et al. 2012; Guo et al. 2017a, 2017b). Additionally, in combination with thorough morphological examinations, a number of previously undescribed genera have been established in the past 12 years (Mols et al. 2008; Couvreur et al. 2009, 2015; Chaowasku et al. 2012, 2013, 2015,2018a, 2018b; Guo et al. 2014; Xue et al. 2018). One of these is the genus Winitia Chaowasku (Chaowasku et al. 2013), which is closely allied to the monotypic genus Stelechocarpus Hook.f. \& Thomson (Hooker \& Thomson 1855) and the genus Sageraea Dalzell (Dalzell 1851) composed of nine species (van Heusden 1997). Despite a rather poor support for the sister relationship of Winitia and Stelechocarpus (Chaowasku et al. 2013), the former was reduced into synonymy of the latter by Turner (2016).

Winitia can be recognized by a suite of morphological traits, e.g., monoecious habit; conspicuously thick, fleshy, and \pm rose-colored petals; multicolumellar stigmas, i.e., each stigma with multiple columnar lobes; rather massive, \pm blackish brown, and multi-seeded monocarps as well as several palynological features (Chaowasku et al. 2013). The genus is distributed from southern Thailand and southern Vietnam through the Malay Peninsula to Sumatra and Borneo, and currently contains two species: the widespread W. cauliflora (Scheff.) Chaowasku (Chaowasku et al. 2013; basionym: Scheffer 1881) and the type species $W$. expansa Chaowasku (Chaowasku et al. 2013) endemic to Thailand; so far, only a single accession of each species has been included in phylogenetic analyses (Chaowasku et al. 2013: accession of W. cauliflora was from cultivation in Bogor Botanical Garden, Indonesia).

In Gardner et al. (2015: 174) there are photographs of Winitia sp., which occurs in Surat Thani Province of Thailand and superficially resembles $W$. expansa, especially in the inner petals spreading at anthesis, but some features are different. Further, W. cauliflora occurring in Thailand has never been included in any phylogenetic inferences. The aims of the present study are, therefore, to (1) elucidate the phylogenetic position of Winitia sp. from Surat Thani Province and $W$. cauliflora accessions from Thailand and (2) determine their taxonomic status. The additional accessions will also provide a test of the monophyly of the genus.

\section{Material and methods}

\section{Taxon and character samplings}

Fifty-six accessions comprised the ingroup with representatives of all currently recognized tribes of the Annonaceae subfamily Malmeoideae Chatrou, Pirie, Erkens \& Couvreur except Piptostigmateae Chatrou \& R.M.K.Saunders (Mwasumbia alba Couvreur \& D.M.Johnson [Couvreur et al. 2009] and Brieya fasciculata De Wild. [De Wildeman 1914]), which were assigned as outgroups, and Annickieae Couvreur. The Malmeoideae minus Piptostigmateae and Annickieae have been previously shown to constitute a strongly supported clade (e.g., Guo et al. 2017b). For Miliuseae Hook.f. \& Thomson, the largest tribe of Malmeoideae, representatives of all genera currently recognized were included. Seven accessions of Winitia were included: two accessions of Winitia sp. (= Winitia aff. expansa) from Surat Thani Prov., Thailand, one accession of $W$. expansa (endemic to Thailand) and four accessions of $W$. cauliflora (two from Nakhon Si Thammarat Prov., Thailand, another two from cultivation in Bogor Botanical Garden, Indonesia), together with two accessions of Stelechocarpus burahol (Blume) Hook.f. \& Thomson (Hooker \& Thomson 1855; basionym: Blume 1825), the sister group of Winitia, and two accessions of Sageraea, another genus closely allied to Winitia. Appendix 1 shows voucher information of the 58 accessions. Seven plastome regions were used in this study; they were composed of four exons 
$(m a t \mathrm{~K}, n d h \mathrm{~F}, r b c \mathrm{~L}$, and $y c f 1)$, one intron $(\operatorname{trn} \mathrm{L})$, and two intergenic spacers ( $p s b \mathrm{~A}-\operatorname{trn} \mathrm{H}, \operatorname{trn} \mathrm{L}-\operatorname{trn} \mathrm{F})$. The $y c f 1$ sequences of the outgroups plus Monocarpia euneura Miq. (Miquel 1865) were not available.

\section{DNA extraction, amplification and sequencing}

All methods used for DNA extraction, amplification, and sequencing in the present study were the same as those described in Chaowasku et al. (2018a), with the same primer sequences as used in Chaowasku et al. (2012) except for the $p s b A-t r n H$ intergenic spacer, which used Fw-GTTATGCATGAACGTAATGCTC (Sang et al. 1997) and Rv-CGCGCATGGTGGATTCACAATCC (Tate \& Simpson 2003).

\section{Phylogenetic analyses}

Sequences were edited using the Staden package (Staden et al. 2000; available from http://staden.sourceforge.net/) and subsequently aligned by Multiple Sequence Comparison by LogExpectation (MUSCLE; Edgar 2004) in MEGA7 (Kumar et al. 2016). The alignments were then manually optimized on the basis of homology assessment using the similarity criterion (Simmons 2004). A total of 7026 nucleotide plus nine non-autapomorphic indel characters were included. Indel coding followed the simple method of Simmons \& Ochoterena (2000). An inversion of 15 continuous nucleotides in the $p s b \mathrm{~A}-t r n \mathrm{H}$ intergenic spacer was observed in some sequences and changed to its reverse complement to be homologically alignable to the remaining sequences, following Pirie et al. (2006). Parsimony analysis was carried out in TNT ver. 1.5 (Goloboff \& Catalano 2016). All characters were equally weighted and unordered. Incongruence among regions was evaluated by individually analyzing each region to see if there was any significant conflict in clade support (e.g., Wiens 1998). Multiple most parsimonious trees were produced by a heuristic search of the combined data, with 9000 replicates of random sequence addition, saving 10 trees per replicate, and using the tree bisection and reconnection (TBR) branch-swapping algorithm. Clade support was measured by symmetric resampling (SR; Goloboff et al. 2003). A default change probability was used. One hundred thousand replicates were run, each with four replicates of random sequence addition, saving four trees per replicate. A clade with SR $\geq 85 \%, 70-84 \%$ or $50-69 \%$ was regarded as strongly, moderately or weakly supported, respectively.

Maximum likelihood analysis was accomplished in IQ-TREE ver. 1.6.10 (Nguyen et al. 2015) using partition models (Chernomor et al. 2016) employed under the "-spp" command, whereas Bayesian Markov chain Monte Carlo (MCMC; Yang \& Rannala 1997) phylogenetic analysis was implemented in MrBayes ver. 3.2.6 (Ronquist et al. 2012). Both analytical methods were performed via the CIPRES Science Gateway ver. 3.3 (Miller et al. 2010). The data matrix was divided into seven partitions based on DNA region identity (the $\operatorname{tr} n \mathrm{~L}$ intron and the adjacent $\operatorname{trn} \mathrm{L}-\operatorname{trn} \mathrm{F}$ intergenic spacer were united as a single partition) plus a binary indel-coded partition. The most suitable model of sequence evolution for each DNA partition was chosen by Akaike Information Criterion (AIC) scores, using FindModel (http://www.hiv.lanl.gov/content/sequence/findmodel/findmodel.html) (Posada \& Crandall 1998). The General Time Reversible (GTR; Tavare 1986) nucleotide substitution model with a gamma distribution for among-site rate variation was chosen for five partitions $(m a t \mathrm{~K}, n d h \mathrm{~F}, r b c \mathrm{~L}, \operatorname{trn} \mathrm{LF}[=\operatorname{trn} \mathrm{L}$ intron + $\operatorname{trn} \mathrm{L}-\operatorname{trn} \mathrm{F}$ intergenic spacer] and $y c f 1$ ) and the Hasegawa-Kishino-Yano (HKY; Hasegawa et al. 1985) substitution model with a gamma distribution for among-site rate variation was chosen for the remaining partition (psbA-trnH).

In the maximum likelihood analysis, the model "JC2+FQ+ASC" was selected by corrected AIC scores for the binary indel partition. Clade support was evaluated by non-parametric bootstrap resampling method (BS; Felsenstein 1985) with 2000 replicates. A clade with BS $\geq 85 \%, 70-84 \%$ or $50-69 \%$ was regarded as strongly, moderately or weakly supported, respectively. In the Bayesian analysis, the "coding=variable" setting was chosen for the binary indel partition, which was employed with a simple F81-like model without a gamma distribution for among-site rate variation. Three independent analyses, each using four MCMC chains, were simultaneously run; each run was set for 10 million generations. The 
default prior settings were used except for the prior parameter of rate multiplier ("ratepr" [=variable]). The temperature parameter was set to 0.08 . Trees and all parameter values were sampled every $1000^{\text {th }}$ generation. Convergence was assessed by checking the standard deviation of split frequencies of the runs with values $<0.01$ interpreted as indicating a good convergence and by checking for adequate effective sample sizes (ESS > 200) using Tracer ver. 1.6 (Rambaut et al. 2013). The first $25 \%$ of all trees sampled were removed as burn-in, and the $50 \%$ majority-rule consensus tree was constructed from the remaining trees. A clade with posterior probabilities (PP) $\geq 0.95,0.9-0.94$ or $0.5-0.89$ was regarded as strongly supported, weakly supported or unsupported, respectively.

\section{Morphology}

The indumentum terminology used followed Hewson (1988). When there was a single observation or measurement, the word 'circa' (ca) was added before. Appendix 2 indicates a list of ten specimens morphologically studied.

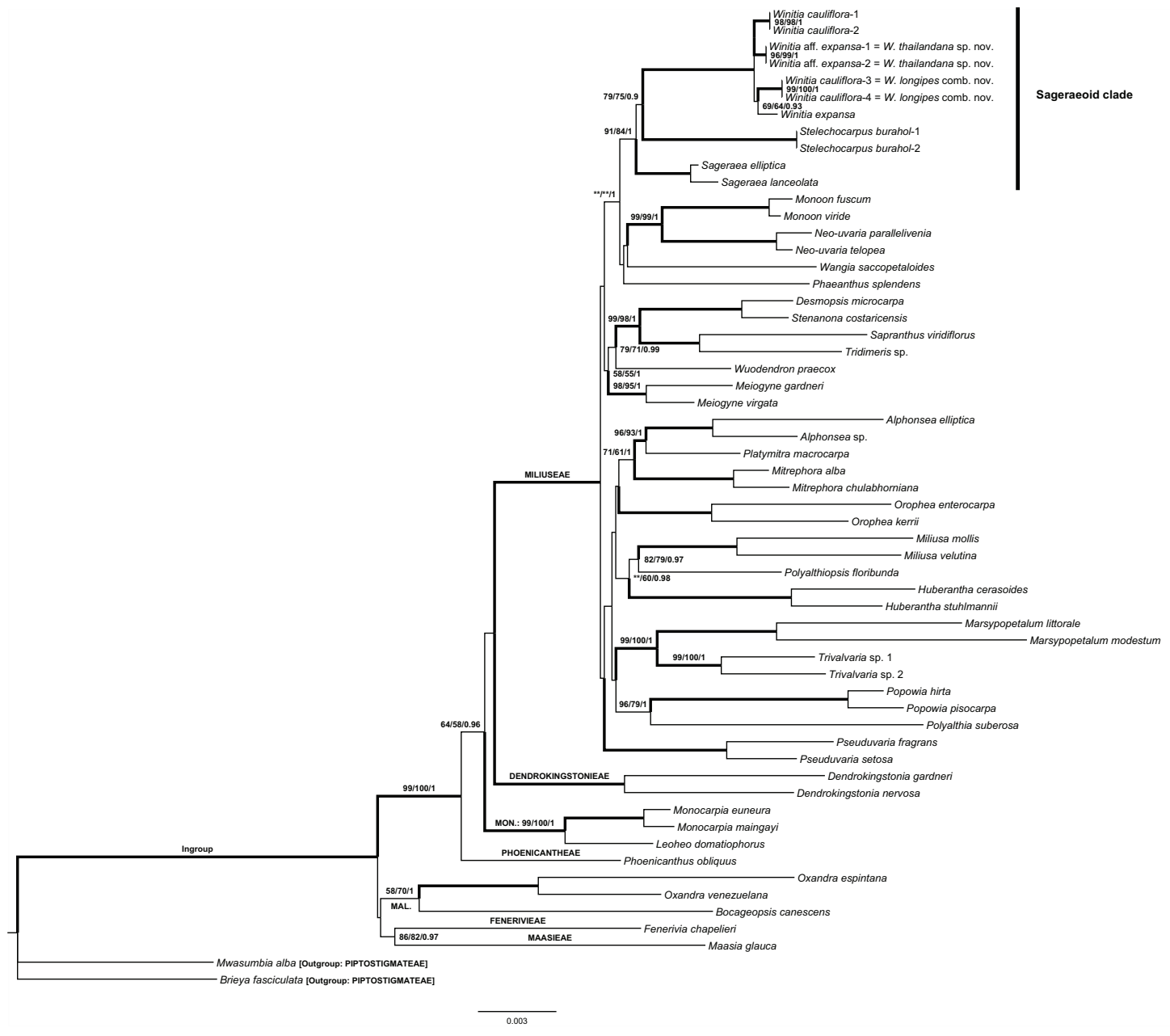

Fig. 1. Phylogram derived from maximum likelihood analysis, with support values shown: SR/BS/PP. Maximally supported clades are represented by thick branches without support values shown; strongly supported clades are represented by thick branches with support values shown; branches without support values shown signify $\mathrm{SR}<50 \%$, BS $<50 \%$, and $\mathrm{PP}<0.85$. ** signifies $\mathrm{SR} / \mathrm{BS}<50 \%$. Scale bar unit $=$ substitutions per site. MAL. $=$ Malmeeae; MON. $=$ Monocarpieae. 


\section{Results}

\section{Phylogenetic analyses}

There was no strong topological conflict (SR $\geq 85 \%$ ) in the analysis of each plastome region. The parsimony analysis resulted in 188 most parsimonious trees with 2258 steps. The consistency and retention indices (CI and RI) were 0.74 and 0.71, respectively. As depicted in Fig. 1, the ingroup and tribe Miliuseae received maximum support. In Miliuseae, three genera (Sageraea, Stelechocarpus, and Winitia) constituted the sageraeoid clade, with each genus maximally supported for its monophyly. The sageraeoid clade received moderate to strong support (SR 91\%, BS 84\%, PP 1), with Stelechocarpus and Winitia being weakly to moderately supported (SR 79\%, BS 75\%, PP 0.9) as sister groups. In Winitia, there was a trichotomy consisting of (1) a strongly supported clade (SR 96\%, BS 99\%, PP 1) of two accessions of Winitia aff. expansa from Surat Thani Prov., Thailand, (2) a strongly supported clade (SR $98 \%$, BS 98\%, PP 1) comprising $W$. cauliflora-1 and $W$. cauliflora-2, each from a different individual cultivated in Bogor Botanical Garden, Indonesia, and (3) a weakly supported clade (SR 69\%, BS 64\%, PP 0.93) composed of $W$. expansa plus two accessions of $W$. cauliflora from Nakhon Si Thammarat Prov., Thailand ( $W$. cauliflora-3 and $W$. cauliflora-4); these Thai accessions of $W$. cauliflora were retrieved as a strongly supported clade (SR 99\%, BS 100\%, PP 1).

Upon a closer observation at part of the multiple sequence alignment of the $\operatorname{trn} \mathrm{L}-\operatorname{trn} \mathrm{F}$ intergenic spacer, it is clear that Winitia and Stelechocarpus differ from each other by having dissimilar indel structures: absence of a gap in Winitia vs presence of a gap in Stelechocarpus (Fig. 2). This eight-base-pair indel is one of the nine indel-coded characters included in the binary indel partition.

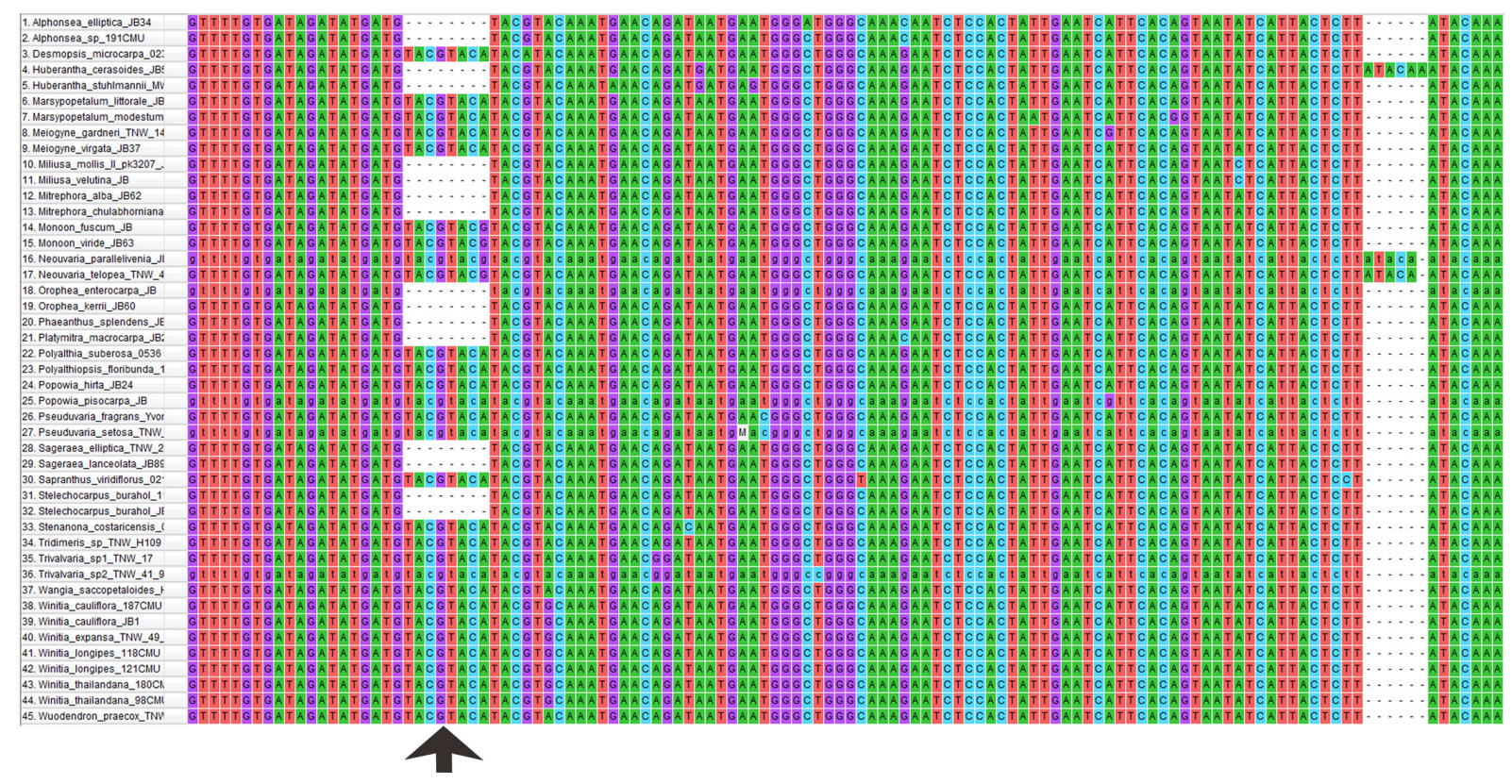

Fig. 2. Part of multiple sequence alignment of $\operatorname{trn} \mathrm{L}-\operatorname{trn} \mathrm{F}$ intergenic spacer, showing an indel (arrow) potentially diagnostic for generic discrimination in Miliuseae. 


\section{Taxonomy}

Order Magnoliales Juss. ex Bercht. \& J.Pres1

Family Annonaceae Juss., nom. cons.

Tribe Miliuseae Hook.f. \& Thomson

Genus Winitia Chaowasku

Winitia longipes (Craib) Chaowasku \& Aongyong comb. nov.

urn:lsid:ipni.org:names:77209777-1

Fig. 3B, D, F, H

इStelechocarpus longipes Craib, The Journal of the Natural History Society of Siam 6: 43 (Craib 1923).

Type: THAILAND · Khao Rum [Nakhon Si Thammarat Prov.]; fl; Native Collector s.n. (Herb. Eryl Smith 643); holotype: K[K000382080]; isotype: BK.

\section{Notes}

From Fig. 1, it is apparent that the four accessions of $W$. cauliflora did not form a clade. There are two strongly supported clades of W. cauliflora: one consisting of Winitia cauliflora-1 and Winitia cauliflora-2, both cultivated in Bogor Botanical Garden, Indonesia, and another comprising Winitia cauliflora-3 and Winitia cauliflora-4, both from Nakhon Si Thammarat Prov., Thailand. The latter clade is the sister group of $W$. expansa endemic to Phatthalung Prov. of Thailand, though with only weak support. According to van Heusden (1995), the type of Sageraea cauliflora Scheff., which is the basionym of $W$. cauliflora, was from cultivation in Bogor Botanical Garden, Indonesia (Cult. Hort. Bog. IV-H-58, origin: Indonesia, Sumatra, Prov. Lampong). The samples Winitia cauliflora-1 and Winitia cauliflora-2 were collected from individual X-F-96 and individual XV-A-196, respectively, whereas the living individual IV-H-58 could not be found, probably this individual has died. The morphology of Winitia cauliflora-1 and Winitia cauliflora-2 is very much in agreement with that of the type specimens (Scheffer 1881; neotype: L [L 0038174] and possible isoneotype: L [L 0038175]), but is different from that of Winitia cauliflora-3 and Winitia cauliflora-4 in several respects, i.e., petal size and shape, and stamen and stigma morphology (Table 1, Fig. 3). On the basis of combined molecular phylogenetic and morphological evidence, Winitia cauliflora-3 and Winitia cauliflora-4 should be classified in a species distinct from W. cauliflora. The name Stelechocarpus longipes Craib (Craib 1923) is available and its type specimens, which were also collected in Nakhon Si Thammarat Prov., Thailand (holotype: http://specimens.kew.org/herbarium/K000382080), is morphologically similar to Winitia cauliflora-3 and Winitia cauliflora-4 regarding leaves, inflorescences, and flowers. Therefore, a new combination in Winitia for Stelechocarpus longipes is made. It should be noted that although the name Stelechocarpus nitidus King (King 1892) is older, its type specimens collected from Perak, Malay Peninsula (lectotype: http://specimens.kew.org/herbarium/K000382081) exhibit petals that are similar in size and shape to those of Winitia cauliflora-1 and Winitia cauliflora-2 (Table 1, Fig. 3A); hence, for now we still consider it as a junior synonym of $W$. cauliflora until more evidence is obtained.

On the basis of personal observations by the second author, $W$. longipes is generally found near streams. During monsoon seasons, the areas where this species occurs are shortly flooded, and it is possible that the ripe monocarps fallen on the ground are taken away by the water current. Sometimes the seeds are found germinated despite still being partially covered by the pericarp. Winitia longipes is widespread in Nakhon Si Thammarat and neighboring provinces where several protected areas are located, but many individuals do occur outside the protected areas; these unprotected forests diminish nearly every single day due mainly to agricultural expansion (pers. obs.). Therefore, we recommend that its conservation status based on IUCN (2012) be assessed as "Near Threatened (NT)". 

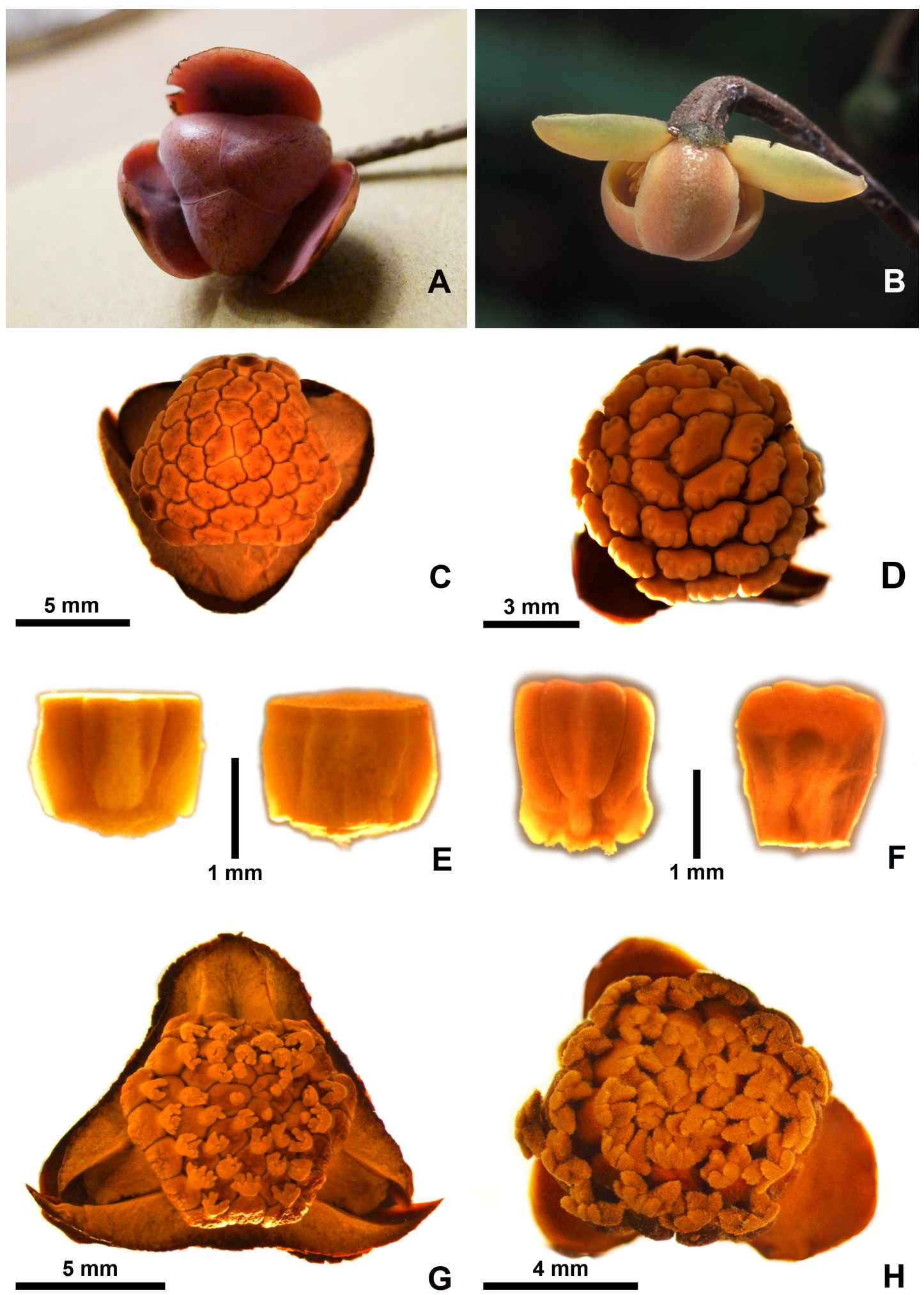

Fig. 3. Flowers and floral organs of Winitia cauliflora (Scheff.) Chaowasku (A, C, E, G) and Winitia longipes (Craib) Chaowasku \& Aongyong comb. nov. (B, D, F, H). A-B. Flowers. C-D. Male flowers with petals removed. E-F. Stamens, abaxial (left) and adaxial (right) sides. G-H. Female flowers with petals removed. A, C, E, G from Chaowasku 185 (CMUB); B from Gardner et al. ST1665 (L); D, F, H from Aongyong 8 (CMUB). Photographs by T. Chaowasku (A) and S. Gardner (B). 
Table 1. Principal morphological differences between Winitia cauliflora (Scheff.) Chaowasku and Winitia longipes (Craib) Chaowasku \& Aongyong comb. nov.

\begin{tabular}{lcc}
\hline Features & W. cauliflora & W. longipes comb. nov. \\
\hline $\begin{array}{l}\text { Outer petal size }(\mathrm{mm}) \\
\text { and shape }\end{array}$ & $9-12 \times 13-14$, & $12.5 \times 8.5-10$, \\
Inner petal size $(\mathrm{mm})$ & broadly ovate & elliptic to slightly ovate \\
and shape & $10.5-12 \times 7.5-9$, & $8.5-9 \times 8-8.5$, \\
& slightly obovate to obovate & elliptic to slightly ovate \\
Stamens & Tightly packed, & More loosely packed, \\
& not bending inward & slightly bending inward \\
Stigmas & Generally with $\geq 10$ columnar lobes & With 5-7 columnar lobes per stigma; \\
& per stigma; lobes not deeply divided & lobes deeply divided \\
\hline
\end{tabular}

The phylogenetic results (Fig. 1) revealed that Winitia aff. expansa-1 and Winitia aff. expansa-2 formed a strongly supported clade, which is not the sister group of $W$. expansa. Although $W$. expansa as well as Winitia aff. expansa-1 and Winitia aff. expansa-2 exhibit inner petals that are spreading at anthesis (Fig. 4A-B), the latter two accessions differ from $W$. expansa by having a non-glaucous appearance on the petal adaxial surface (Fig. 4A-B; glaucous in W. expansa; Chaowasku et al. 2013) and shallow pits on the adaxial surface of the inner petals (Fig. 4B; no pitted structures in W. expansa; Chaowasku et al. 2013). In addition, the inflorescences of Winitia aff. expansa-1 and Winitia aff. expansa-2 are mostly clustered on large roots and at the unswollen base of trunks, while those of $W$. expansa are mostly clustered at the swollen base of trunks. Based on the above-mentioned differences, Winitia aff. expansa is described as new to science.

Winitia thailandana Chaowasku \& Aongyong sp. nov. urn:lsid:ipni.org:names:77209778-1

Figs 4-6

\section{Diagnosis}

Morphologically similar to Winitia expansa, differs by having a non-glaucous appearance on the petal adaxial surface (glaucous in $W$. expansa) and shallow pits on the adaxial surface of the inner petals (no pitted structures in $W$. expansa). Moreover, its inflorescences are mostly clustered on large roots and at the unswollen base of trunks, whereas the inflorescences of $W$. expansa are mostly clustered at the swollen base of trunks.

\section{Etymology}

Named after Thailand, a country where this species is endemic.

\section{Type material}

\section{Holotype}

THAILAND - Surat Thani Prov., Phanom Distr.; 8 May 2017; fl; Aongyong 9; holotype: CMUB; isotypes: $\mathrm{G}, \mathrm{P}$.

\section{Paratypes}

THAILAND • Surat Thani Province, Phanom District; fl; Chaowasku 51; CMUB • Khlong Phanom National Park; fl; Gardner \& Sidisunthorn ST0817; L. 


\section{Description}

Medium-sized trees 12-14 m tall, dbh ca $27 \mathrm{~cm}$. Young twigs glabrous. Petiole 6-8 mm long, grooved on upper surface, glabrous on both surfaces; leaf blade elliptic to slightly ovate, 13-17.8 $\times 3.7-5.8 \mathrm{~cm}$, glabrous on both surfaces, in young leaves numerous black dots present on lower surface, base broadly cuneate to obtuse, apex acute-acuminate to acuminate; midrib raised and glabrous on both surfaces, in young leaves numerous black dots present on lower surface; secondary veins 8-10 per side, rather prominent on lower surface and forming loops, angle with midrib $50^{\circ}-60^{\circ}$ (at middle part of leaf blade). Flowers fasciculate, mostly clustered on large roots and at unswollen base of trunks, up to 3 flowers per fascicle, possibly unisexual [only male flowers found]; peduncle when present inconspicuous; pedicel 7-15 mm long, appressed-puberulous, bracts 2(-3), triangular, placed at base, sometimes a bit higher for upper one. Sepals basally connate, triangular-ovate to broadly triangular-ovate, $4.5-5.1 \times 3-5 \mathrm{~mm}$, outside appressed-puberulous, inside and margin glabrous. Outer petals ovate to broadly ovate, 10-11 $\times$ 9-10 mm, indumentum similar to sepals, outside with scattered warts, inside non-glaucous, apex
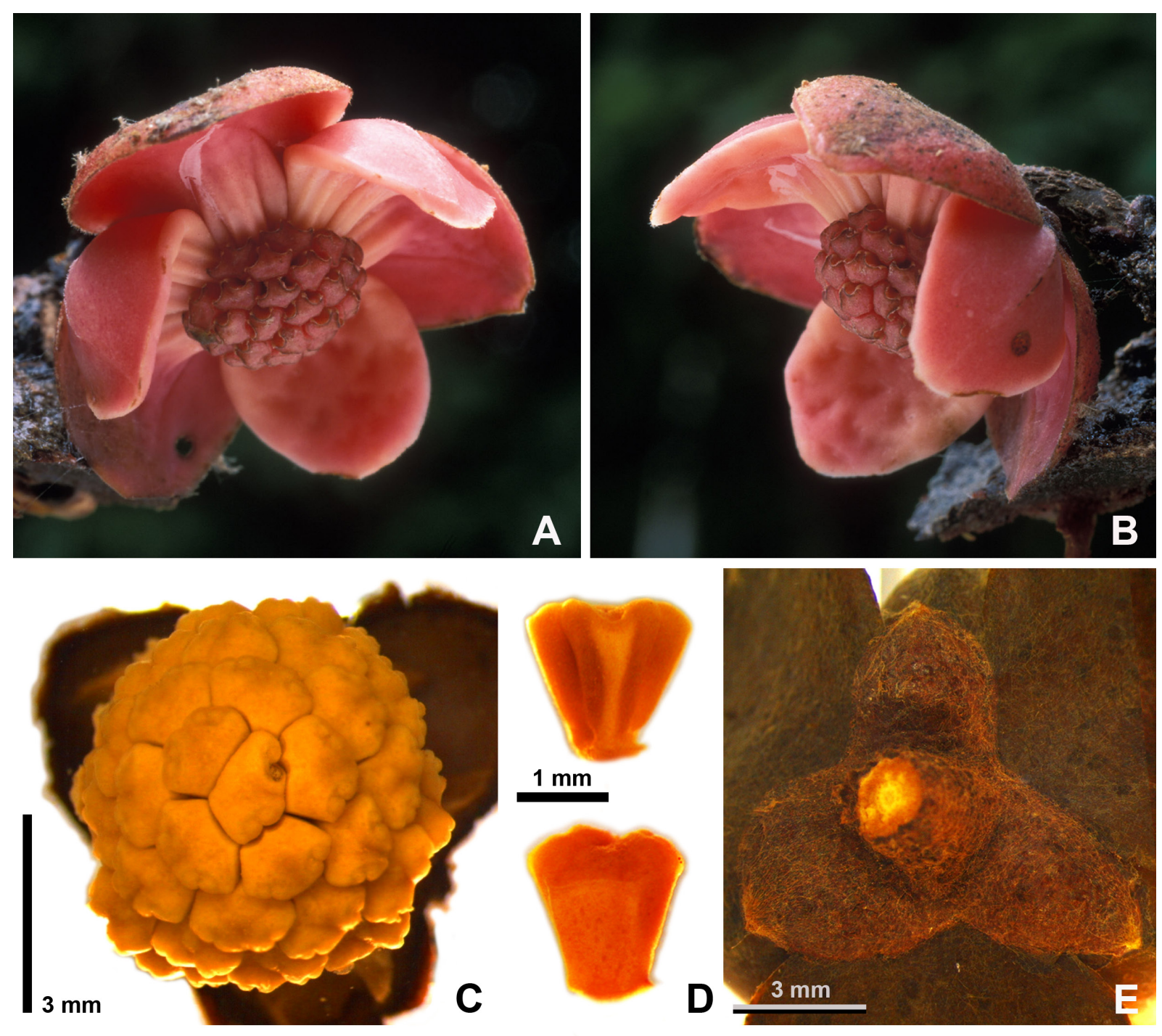

Fig. 4. Flowers and floral organs of Winitia thailandana Chaowasku \& Aongyong sp. nov. A-B. Flower. C. Flower with petals removed. D. Stamen, abaxial (above) and adaxial (below) sides. E. Back side of flower, showing sepals (abaxial side). A, B from Gardner \& Sidisunthorn ST0817 (L), photographs by S. Gardner; C-E from Aongyong 9 (CMUB). 


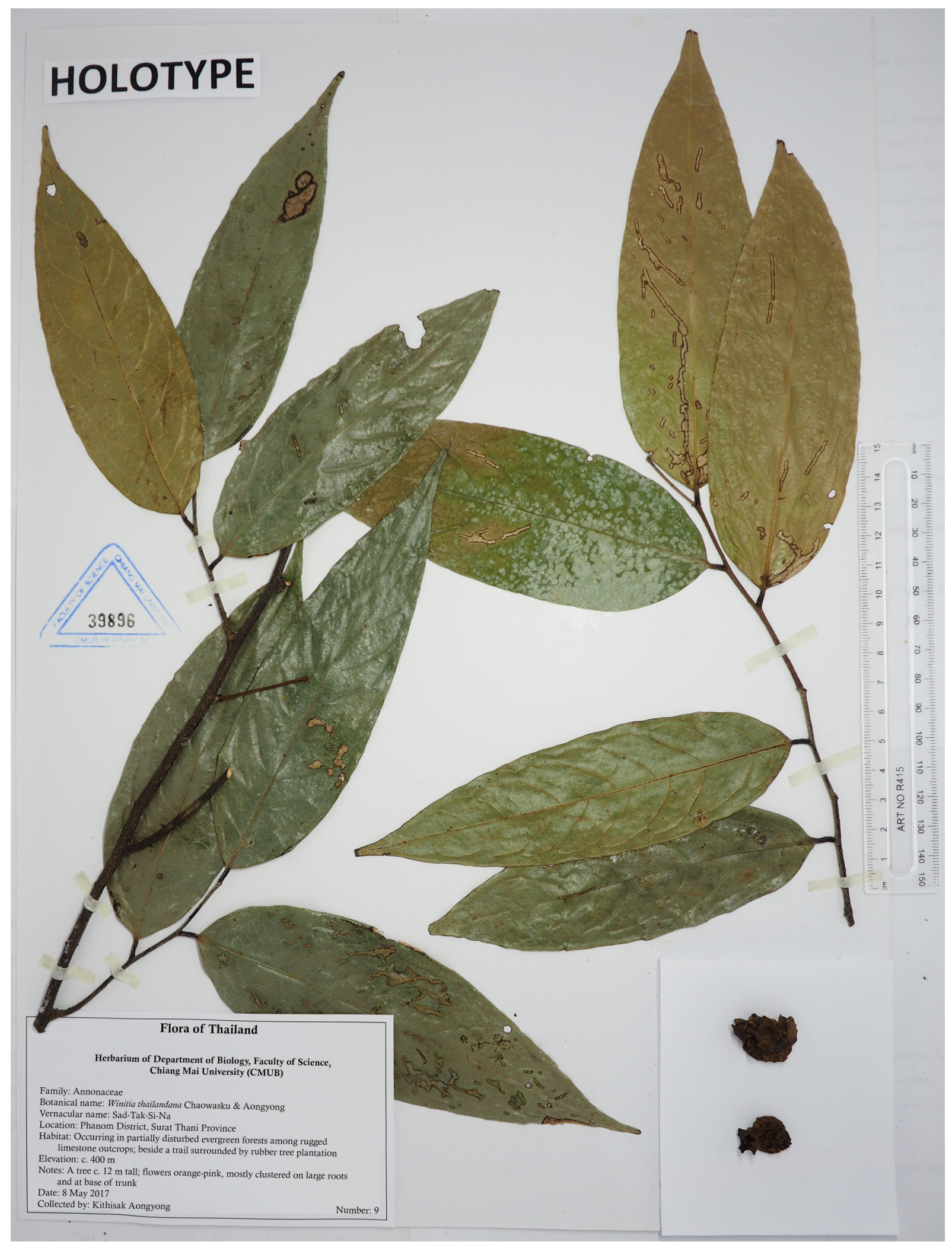

Fig. 5. Holotype of Winitia thailandana Chaowasku \& Aongyong sp. nov. at CMUB. 
between acute and obtuse; inner petals elliptic, $9-10 \times 6 \mathrm{~mm}$, glabrous on both sides and margin, inside non-glaucous and with shallow pits, apex obtuse to rounded. Torus elongated hemispherical in male flowers, glabrous. Stamens 32-39 per male flower, 1.8-2 mm long, tightly packed, each not bending inward, connective apex \pm truncate, not covering thecae; female flowers not found. Monocarps unknown.

\section{Distribution, habitat, and phenology}

Surat Thani Province, Phanom District (Fig. 6); occurs in evergreen forests among rugged limestone outcrops; at an elevation of ca $400 \mathrm{~m}$; flowering material collected in May and June.

\section{Field notes}

Flowers orange-pink.

\section{Notes}

The new species is so far known only from Phanom District. We observed only three individuals, which occur among limestone outcrops beside a trail surrounded by a rubber tree plantation. In Khlong Phanom National Park where this species has also been reported (Gardner et al. 2015) less than ten individuals were found (pers. comm., S. Gardner). Based on our observations and estimations, we believe at least the category "endangered: EN D" (IUCN 2012) is applicable.

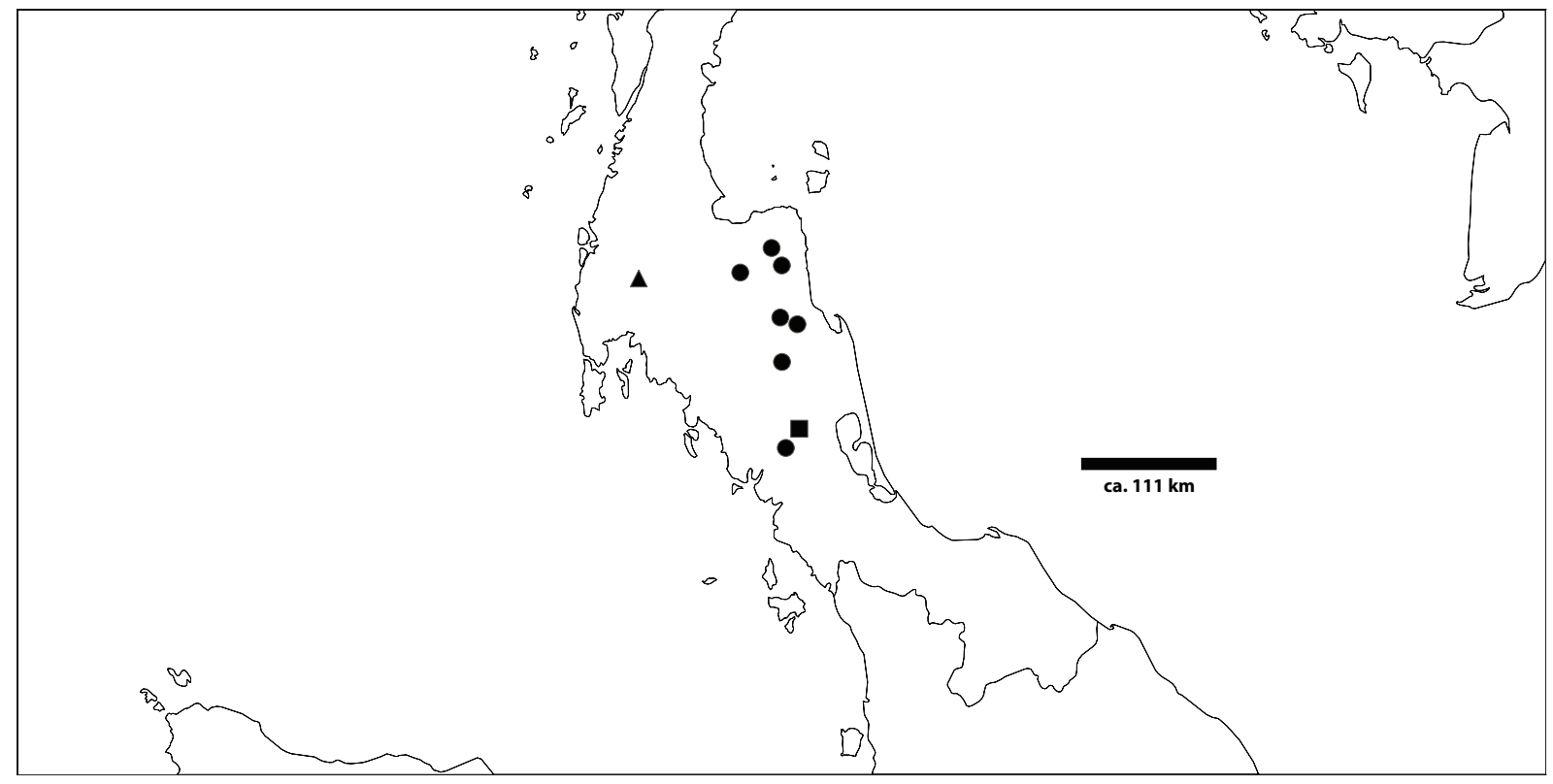

Fig. 6. Distribution of Winitia in Thailand. Winitia expansa Chaowasku (๘), Winitia longipes (Craib) Chaowasku \& Aongyong comb. nov. (•), and Winitia thailandana Chaowasku \& Aongyong sp. nov. $(\boldsymbol{\Delta})$.

\section{Key to genera in the sageraeoid clade}

1. Plants bisexual or monoecious. Leaf midrib sunken on adaxial side, leaf venation (especially secondary veins) generally indistinct

- Plants monoecious. Leaf midrib raised on adaxial side, leaf venation (especially secondary veins) distinct 
2. Flowers dimorphic (in the same individual male flowers smaller with shorter pedicels, female flowers larger with longer pedicels); male and female flowers allocated spatially differently (male flowers ramiflorous, female flowers cauliflorous); petals greenish yellow to cream at maturity, each stigma bilobed ( \pm heart-shaped), torus conical-cylindrical to cylindrical in male flowers; monocarps light brown at maturity ............... Stelechocarpus Hook.f. \& Thomson (Hooker \& Thomson 1855)

- Flowers monomorphic; male and female flowers intermixed and clustered along trunks, at swollen or unswollen base of trunks, and/or on large roots; petals \pm rose-colored at maturity, each stigma with multiple $(\geq 5)$ columnar lobes, torus \pm hemispherical in male flowers; monocarps \pm blackish brown at maturity

Winitia Chaowasku (Chaowasku et al. 2013)

\section{Key to the species of Winitia}

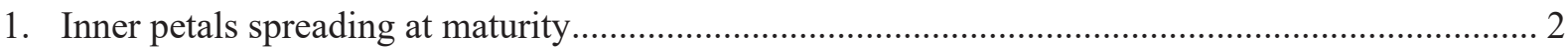

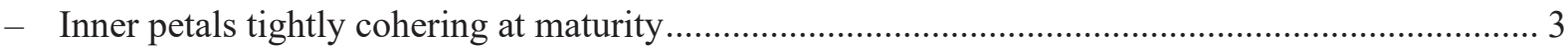

2. Flowers mostly clustered on large roots and at unswollen base of trunks; inner side of both petal whorls without a glaucous appearance, inner side of inner petals with shallow pits .....

Winitia thailandana Chaowasku \& Aongyong sp. nov.

- Flowers mostly clustered at swollen base of trunks; inner side of both petal whorls with a glaucous appearance; inner side of inner petals without pitted structures Winitia expansa Chaowasku (Chaowasku et al. 2013)

3. Outer petals broadly ovate, $9-12 \times 13-14 \mathrm{~mm}$; inner petals slightly obovate to obovate, $10.5-12 \times$ 7.5-9 mm; stamens tightly packed, not bending inward; each stigma generally with $\geq 10$ columnar lobes, lobes not deeply divided

Winitia cauliflora (Scheff.) Chaowasku (Chaowasku et al. 2013; basionym: Scheffer 1881)

- Outer petals elliptic to slightly ovate, $12.5 \times 8.5-10 \mathrm{~mm}$; inner petals elliptic to slightly ovate, $8.5-9 \times 8-8.5 \mathrm{~mm}$; stamens more loosely packed, slightly bending inward (best observable in outer-whorl ones); each stigma with 5-7 columnar lobes, lobes deeply divided Winitia longipes (Craib) Chaowasku \& Aongyong comb. nov.

\section{Discussion}

The monophyly of Winitia, when more accessions have been added, remains maximally supported (Fig. 1), as compared with previous studies that included only two accessions (Chaowasku et al. 2013, 2018b; Guo et al. 2017b). The genus, however, was subsumed under Stelechocarpus by Turner (2016), principally based on the arguments that (1) the erection of Winitia has caused Stelechocarpus to become a monotypic genus, which conveys little taxonomic information, and (2) Stelechocarpus inclusive of Winitia is identifiable by a raised leaf midrib adaxially. However, there are also clear morphological differences, including petal color and texture, floral dimorphism (absent vs present), locations of male and female flowers in individuals (mixed vs separate), and stamen and stigma morphology that warrants the recognition of two separate genera (Chaowasku et al. 2013). These differences are comparable to those of two sister monotypic genera, Mwasumbia Couvreur \& D.M.Johnson (Couvreur et al. 2009) and Sirdavidia Couvreur \& Sauquet (Couvreur et al. 2015), belonging to the African tribe Piptostigmateae of subfamily Malmeoideae and primarily differing from each other in petal color and configuration as well as stamen morphology. Furthermore, support for the sister relationship of Mwasumbia and Sirdavidia was already strong with only three plastid regions $(r b c \mathrm{~L}$ exon, $\operatorname{trn} \mathrm{L}$ intron, and $\operatorname{trn} \mathrm{L}-\operatorname{trn} \mathrm{F}$ intergenic spacer; Couvreur et al. 2015) included, whereas support for the sister relationship of Winitia and Stelechocarpus is still rather poor and the branch uniting the two genera is very short (Fig. 1) despite using seven plastid regions and adding more accessions. In addition, the branches leading to Winitia and to Stelechocarpus are relatively long (Fig. 1) and comparable to those leading to Monoon Miq. (Miquel 
1865 ) and to Neo-uvaria Airy Shaw (Airy Shaw 1939). Given the same amounts of nucleotide data, the support for the sister relationship of Monoon and Neo-uvaria is even much higher with a longer branch uniting them (Fig. 1).

It is worth noticing that there is an indel of eight continuous base pairs in the $\operatorname{trn} \mathrm{L}-\operatorname{trn} \mathrm{F}$ intergeneric spacer potentially diagnostic for generic discrimination in the tribe Miliuseae (Fig. 2), i.e., all members in the same genus possess the same indel structure (absence or presence of an eight-base-pair gap; personal observations based on all GenBank accessions of the $\operatorname{trn} \mathrm{L}-\operatorname{trn} \mathrm{F}$ intergeneric spacer indicated in Chaowasku et al. 2014, 2018a, 2018b; Guo et al. 2017b). This gap is present in Stelechocarpus and absent in Winitia (Fig. 2). Besides Miliuseae, members of other tribes of Malmeoideae and other subfamilies also possess this indel (pers. obs.), but its utility for generic discrimination is still unknown, awaiting detailed observations.

Regarding pollen morphology, the two genera do not possess the same infratectum type, i.e., \pm columellate/coarsely granular in Winitia vs finely and densely granular in Stelechocarpus (Chaowasku et al. 2013); in Miliuseae, there have been no reports of different infratectal structures occurring in the same genus (Chaowasku et al. 2014). There are also other palynological traits (exine sculpturing, tectum, and basal layer) that are significantly different in the two genera (Chaowasku et al. 2013).

In recognizing the genus Winitia, we believe that the most important issue to consider is the support for monophyly, then the morphological distinctions as well as relative phylogenetic branch lengths. On the basis of the above-mentioned morphological and phylogenetic evidence reaffirming a clear-cut differentiation of Winitia and Stelechocarpus, we are therefore strongly convinced that the recognition of the genus Winitia is appropriate. Rather equivalent to the case of Winitia and Stelechocarpus, in Annonaceae acceptance of a non-monotypic genus being the sister group of a monotypic genus is not unprecedented, for example, Fusaea (Baill.) Saff. (Safford 1914; basionym: Baillon 1868) with a monotypic Duckeanthus R.E.Fr. (Fries 1934) as the sister group, Letestudoxa Pellegr. (Pellegrin 1920) with a monotypic Pseudartabotrys Pellegr. (Pellegrin 1920) as the sister group, and Mitrella Miq. (Miquel 1865) with a monotypic Pyramidanthe Miq. (Miquel 1865) as the sister group (see Guo et al. 2017b).

\section{Acknowledgements}

The authors would like to kindly thank the BK, BKF, CMUB, G, K, L, and P herbaria for the material studied. This study was partially financially supported by Chiang Mai University. Simon Gardner and Pindar Sidisunthorn gratefully provided color photographs. Two anonymous reviewers considerably improved an earlier draft of this publication.

\section{References}

Airy Shaw H.K. 1939. Additions to the flora of Borneo and other Malay Islands: XII. The Annonaceae of the Oxford University expedition to Sarawak, 1932. Bulletin of Miscellaneous Information, Royal Botanic Gardens, Kew 1939: 275-290.

Baillon H. 1868. Mémoire sur la famille des Anonacées. Adansonia 8: 295-344.

Blume C.L. von 1825. Bijdragen tot de Flora van Nederlandsch Indië. Part 1. Lands Drukkerij, Batavia [Jakarta].

Chaowasku T., Johnson D.M., van der Ham R.W.J.M. \& Chatrou L.W. 2012. Characterization of Hubera (Annonaceae), a new genus segregated from Polyalthia and allied to Miliusa. Phytotaxa 69: 33-56. https://doi.org/10.11646/phytotaxa.69.1.6 
Chaowasku T., van der Ham R.W.J.M \& Chatrou L.W. 2013. Integrative systematics supports the establishment of Winitia, a new genus of Annonaceae (Malmeoideae, Miliuseae) allied to Stelechocarpus and Sageraea. Systematics and Biodiversity 11: 195-207.

https://doi.org/10.1080/14772000.2013.806370

Chaowasku T., Thomas D.C., van der Ham R.W.J.M., Smets E.F., Mols J.B. \& Chatrou L.W. 2014. A plastid DNA phylogeny of tribe Miliuseae: insights into relationships and character evolution in one of the most recalcitrant major clades of Annonaceae. American Journal of Botany 101: 691-709.

https://doi.org/10.3732/ajb.1300403

Chaowasku T., Johnson D.M., van der Ham R.W.J.M. \& Chatrou L.W. 2015. Huberantha, a replacement name for Hubera (Annonaceae: Malmeoideae: Miliuseae). Kew Bulletin 70: 23.

https://doi.org/10.1007/S12225-015-9571-Z

Chaowasku T., Damthongdee A., Jongsook H., Ngo D.T., Le H.T., Tran D.M. \& Suddee S. 2018a. Enlarging the monotypic Monocarpieae (Annonaceae, Malmeoideae): recognition of a second genus from Vietnam informed by morphology and molecular phylogenetics. Candollea 73: 261-275. https://doi.org/10.15553/c2018v732a11

Chaowasku T., Damthongdee A., Jongsook H., Nuraliev M.S., Ngo D.T., Le H.T., Lithanatudom P., Osathanunkul M., Deroin T., Xue B. \& Wipasa J. 2018b. Genus Huberantha (Annonaceae) revisited: erection of Polyalthiopsis, a new genus for $H$. floribunda, with a new combination H. luensis. Annales Botanici Fennici 55: 121-137. https://doi.org/10.5735/085.055.0114

Chatrou L.W., Pirie M.D., Erkens R.H.J., Couvreur T.L.P., Neubig K.M., Abbott J.R., Mols J.B., Maas J.W., Saunders R.M.K. \& Chase M.W. 2012. A new subfamilial and tribal classification of the pantropical flowering plant family Annonaceae informed by molecular phylogenetics. Botanical Journal of the Linnean Society 169: 5-40. https://doi.org/10.1111/j.1095-8339.2012.01235.x

Chernomor O., Haeseler A. von \& Minh B.Q. 2016. Terrace aware data structure for phylogenomic inference from supermatrices. Systematic Biology 65: 997-1008. https://doi.org/10.1093/sysbio/syw037

Couvreur T.L.P., van der Ham R.W.J.M., Mbele Y.M., Mbago F.M. \& Johnson D.M. 2009. Molecular and morphological characterization of a new monotypic genus of Annonaceae, Mwasumbia, from Tanzania. Systematic Botany 34: 266-276. https://doi.org/10.1600/036364409788606398

Couvreur T.L.P., Niangadouma R., Sonké B. \& Sauquet H. 2015. Sirdavidia, an extraordinary new genus of Annonaceae from Gabon. PhytoKeys 46: 1-19. https://doi.org/10.3897/phytokeys.46.8937

Couvreur T.L., Helmstetter A.J., Koenen E.J., Bethune K., Brandão R.D., Little S.A., Hervé Sauquet \& Erkens R.H. 2019. Phylogenomics of the major tropical plant family Annonaceae using targeted enrichment of nuclear genes. Frontiers in Plant Science 9: 1941. https://doi.org/10.3389/fpls.2018.01941

Craib W.G. 1923. Six new flowering plants from Siam. Journal of the Natural History Society of Siam 6: $43-45$.

Dalzell N.A. 1851. Contributions to the botany of western India [Anonaceae]. Hooker's Journal of Botany and Kew Garden Miscellany 3: 206-208.

de Wildeman E. 1914. Neue Arten aus Zentral-Afrika (Belgisch-Kongo) I. Repertorium Specierum Novarum Regni Vegetabilis 13: 369-384. https://doi.org/10.1002/fedr.19140132402

Edgar R.C. 2004. MUSCLE: multiple sequence alignment with high accuracy and high throughput. Nucleic Acids Research 32: 1792-1797. https://doi.org/10.1093/nar/gkh340

Felsenstein J. 1985. Confidence limits on phylogenies: an approach using the bootstrap. Evolution 39: 783-791. https://doi.org/10.1111/j.1558-5646.1985.tb00420.x 
Fries R.E. 1934. Revision der Arten einiger Anonaceen-Gattungen III. Acta Horti Bergiani 12: 1-220.

Gardner S., Sidisunthorn P. \& Chayamarit K. 2015. Forest Trees of southern Thailand. Vol. 1: Acanthaceae to Escalloniaceae. Kobfai Printing Project, Bangkok.

Goloboff P.A. \& Catalano S.A. 2016. TNT version 1.5, including a full implementation of phylogenetic morphometrics. Cladistics 32: 221-238. https://doi.org/10.1111/cla.12160

Goloboff P.A., Farris J.S., Källersjö M., Oxelman B., Ramirez M.J. \& Szumik C.A. 2003. Improvements to resampling measures of group support. Cladistics 19: 324-332.

https://doi.org/10.1111/j.1096-0031.2003.tb00376.x

Guo X., Wang J., Xue B., Thomas D.C., Su Y.C.F., Tan Y.H. \& Saunders R.M.K. 2014. Reassessing the taxonomic status of two enigmatic Desmos species (Annonaceae): morphological and molecular phylogenetic support for a new genus, Wangia. Journal of Systematics and Evolution 52: 1-15.

https://doi.org/10.1111/jse.12064

Guo X., Hoekstra P.H., Tang C.C., Thomas D.C., Wieringa J.J., Chatrou L.W. \& Saunders R.M.K. 2017 a. Cutting up the climbers: evidence for extensive polyphyly in Friesodielsia (Annonaceae) necessitates generic realignment across the tribe Uvarieae. Taxon 66: 3-19. https://doi.org/10.12705/661.1

Guo X., Tang C.C., Thomas D.C., Couvreur T.L.P. \& Saunders R.M.K. 2017b. A mega-phylogeny of the Annonaceae: taxonomic placement of five enigmatic genera and recognition of a new tribe, Phoenicantheae. Scientific Reports 7: 7323. https://doi.org/10.1038/s41598-017-07252-2

Hasegawa M., Kishino H. \& Yano T. 1985. Dating of the human-ape splitting by a molecular clock of mitochondrial DNA. Journal of Molecular Evolution 22: 160-174. https://doi.org/10.1007/BF02101694

Hewson H.J. 1988. Plant Indumentum. A Handbook of Terminology. Australian Flora and Fauna Series 9, Australian Government Publishing Service, Canberra.

Hooker J.D. \& Thomson T. 1855. Flora Indica: Being a Systematic Account of the Plants of British India, Together with Observations on the Structure and Affinities of their Natural Orders and Genera. Pamplin, London. https://doi.org/10.5962/bhl.title.57706

IUCN 2012. IUCN Red List categories and criteria. Version 3.1. Second Edition. IUCN, Gland \& Cambridge.

King G. 1892. Materials for a flora of the Malay Peninsula. Journal of the Asiatic Society of Bengal (part 2, Natural Science) 61: 1-130.

Kumar S., Stecher G. \& Tamura K. 2016. MEGA7: molecular evolutionary genetics analysis version 7.0 for bigger datasets. Molecular Biology and Evolution 33: 1870-1874.

https://doi.org/10.1093/molbev/msw054

Miller M.A., Pfeiffer W. \& Schwartz T. 2010. Creating the CIPRES Science Gateway for inference of large phylogenetic trees. In: Proceedings of the Gateway Computing Environments Workshop (GCE): 45-52. IEEE, Piscataway. https://doi.org/10.1109/GCE.2010.5676129

Miquel F.A.W. 1865. Anonaceae Archipelagi Indici. Annales Musei Botanici Lugduno-Batavi 2: 1-45.

Mols J.B., Keßler P.J.A., Rogstad S.H. \& Saunders R.M.K. 2008. Reassignment of six Polyalthia species to the new genus Maasia (Annonaceae): molecular and morphological congruence. Systematic Botany 33: 490-494. https://doi.org/10.1600/036364408785679752

Nguyen L.T., Schmidt H.A., Haeseler A. von \& Minh B.Q. 2015. IQ-TREE: a fast and effective stochastic algorithm for estimating maximum-likelihood phylogenies. Molecular Biology and Evolution 32: 268274. https://doi.org/10.1093/molbev/msu300 
Pellegrin F. 1920. Plantae Letestuanae novae ou Plantes nouvelles récoltées par M. Le Testu de 1907 à 1919 dans le Mayombe congolais. Bulletin du Muséum national d'histoire naturelle 26: 654-659.

Pirie M.D., Chatrou L.W., Mols J.B., Erkens R.H.J. \& Oosterhof J. 2006. 'Andean-centred' genera in the short-branch clade of Annonaceae: testing biogeographic hypotheses using phylogeny reconstruction and molecular dating. Journal of Biogeography 33:31-46. https://doi.org/10.1111/j.1365-2699.2005.01388.x

Posada D. \& Crandall K.A. 1998. MODELTEST: testing the model of DNA substitution. Bioinformatics 14: 817-818. https://doi.org/10.1093/bioinformatics/14.9.817

Rambaut A., Suchard M. \& Drummond A. 2013. Tracer. Version 1.6. Available from http://tree.bio.ed.ac.uk/software/tracer [accessed 18 may 2017].

Ronquist F., Teslenko M., van der Mark P., Ayres D.L., Darling A., Höhna S., Larget B., Liu L., Suchard M.A. \& Huelsenbeck J.P. 2012. MrBayes 3.2: efficient Bayesian phylogenetic inference and model choice across a large model space. Systematic Biology 61: 539-542.

https://doi.org/10.1093/sysbio/sys029

Safford W.E. 1914. Classification of the genus Annona, with descriptions of new and imperfectly known species. Contributions from the United States National Herbarium 18: 1-68.

Sang T., Crawford D.J. \& Stuessy T.F. 1997. Chloroplast DNA phylogeny, reticulate evolution and biogeography of Paeonia (Paeoniaceae). American Journal of Botany 84: 1120-1136.

https://doi.org/10.2307/2446155

Scheffer R.H.C.C. 1881. Sur quelques plantes nouvelles ou peu connues de l'Archipel Indien. Annales du Jardin botanique de Buitenzorg 2: 1-31.

Simmons M.P. 2004. Independence of alignment and tree search. Molecular Phylogenetics and Evolution 31: 874-879. https://doi.org/10.1016/j.ympev.2003.10.008

Simmons M.P. \& Ochoterena H. 2000. Gaps as characters in sequence-based phylogenetic analyses. Systematic Biology 49: 369-381. https://doi.org/10.1093/sysbio/49.2.369

Staden R., Beal K.F. \& Bonfield J.K. 2000. The Staden package, 1998. In: Misener S. \& Krawetz S.A. (eds) Bioinformatics Methods and Protocols. Methods in Molecular Biology ${ }^{\mathrm{TM}}$ : 115-130. Humana Press, Totowa. https://doi.org/10.1385/1-59259-192-2:115

Tate J.A. \& Simpson B.B. 2003. Paraphyly of Tarasa (Malvaceae) and diverse origins of the polyploid species. Systematic Botany 28: 723-737. https://doi.org/10.1043/02-64.1

Tavaré S. 1986. Some probabilistic and statistical problems in the analysis of DNA sequences. Lectures on Mathematics in the Life Science 17: 57-86.

Turner I.M. 2016. Notes on the Annonaceae of the Malay Peninsula. Gardens' Bulletin Singapore 68: 65-69.

van Heusden E.C.H. 1995. Revision of the Southeast Asian genus Stelechocarpus (Annonaceae). Blumea 40: 429-438.

van Heusden E.C.H. 1997. Revision of the southeast Asian genus Sageraea (Annonaceae). Nordic Journal of Botany 17: 39-54. https://doi.org/10.1111/j.1756-1051.1997.tb00289.x

Wiens J.J. 1998. Combining data sets with different phylogenetic histories. Systematic Biology 47: 568581. https://doi.org/10.1080/106351598260581

Xue B., Su Y.C.F., Thomas D.C. \& Saunders R.M.K. 2012. Pruning the polyphyletic genus Polyalthia (Annonaceae) and resurrecting the genus Monoon. Taxon 61: 1021-1039.

https://doi.org/10.1002/tax.615009 
Xue B., Tan Y.H., Thomas D.C., Chaowasku T., Hou X.L. \& Saunders R.M.K. 2018. A new Annonaceae genus, Wuodendron, provides support for a post-boreotropical origin of the Asian-Neotropical disjunction in the tribe Miliuseae. Taxon 67: 250-266. https://doi.org/10.12705/672.2

Yang Z. \& Rannala B. 1997. Bayesian phylogenetic inference using DNA sequences: a Markov Chain Monte Carlo method. Molecular Biology and Evolution 14: 717-724.

https://doi.org/10.1093/oxfordjournals.molbev.a025811

Zhou L., Su Y.C.F. \& Saunders R.M.K. 2009. Molecular phylogenetic support for a broader delimitation of Uvaria (Annonaceae), inclusive of Anomianthus, Cyathostemma, Ellipeia, Ellipeiopsis and Rauwenhoffia. Systematics and Biodiversity 7: 249-258. https://doi.org/10.1017/S1477200009003028

Zhou L., Su Y.C.F., Chalermglin P. \& Saunders R.M.K. 2010. Molecular phylogenetics of Uvaria (Annonaceae): relationships with Balonga, Dasoclema and Australian species of Melodorum. Botanical Journal of the Linnean Society 163: 33-43. https://doi.org/10.1111/j.1095-8339.2010.01045.x

Manuscript received: 27 July 2019

Manuscript accepted: 24 March 2020

Published on: 4 June 2020

Topic editor: Frederik Leliaert

Desk editor: Natacha Beau

Printed versions of all papers are also deposited in the libraries of the institutes that are members of the EJT consortium: Muséum national d'histoire naturelle, Paris, France; Meise Botanic Garden, Belgium; Royal Museum for Central Africa, Tervuren, Belgium; Royal Belgian Institute of Natural Sciences, Brussels, Belgium; Natural History Museum of Denmark, Copenhagen, Denmark; Naturalis Biodiversity Center, Leiden, the Netherlands; Museo Nacional de Ciencias Naturales-CSIC, Madrid, Spain; Real Jardín Botánico de Madrid CSIC, Spain; Zoological Research Museum Alexander Koenig, Bonn, Germany; National Museum, Prague, Czech Republic. 


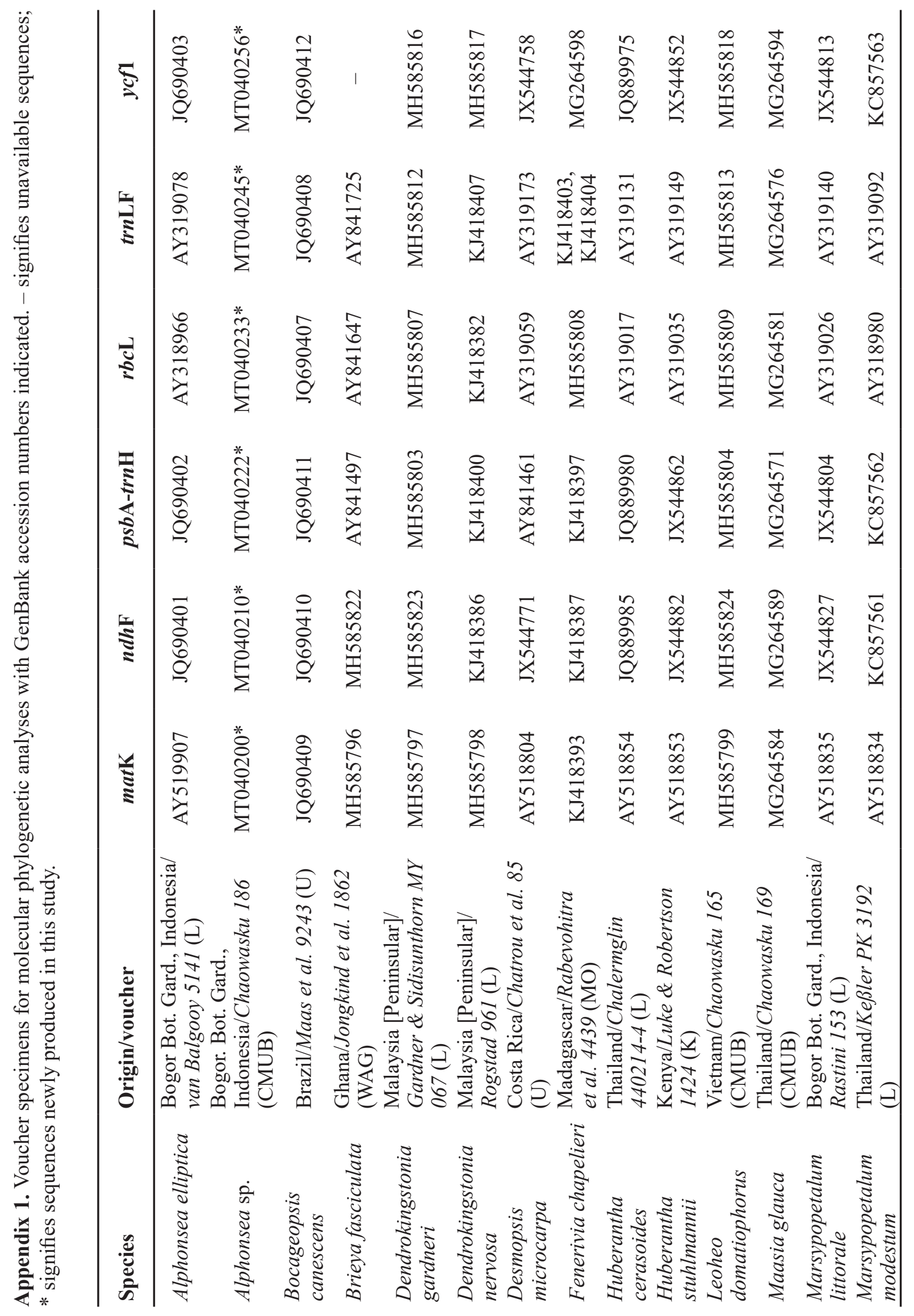




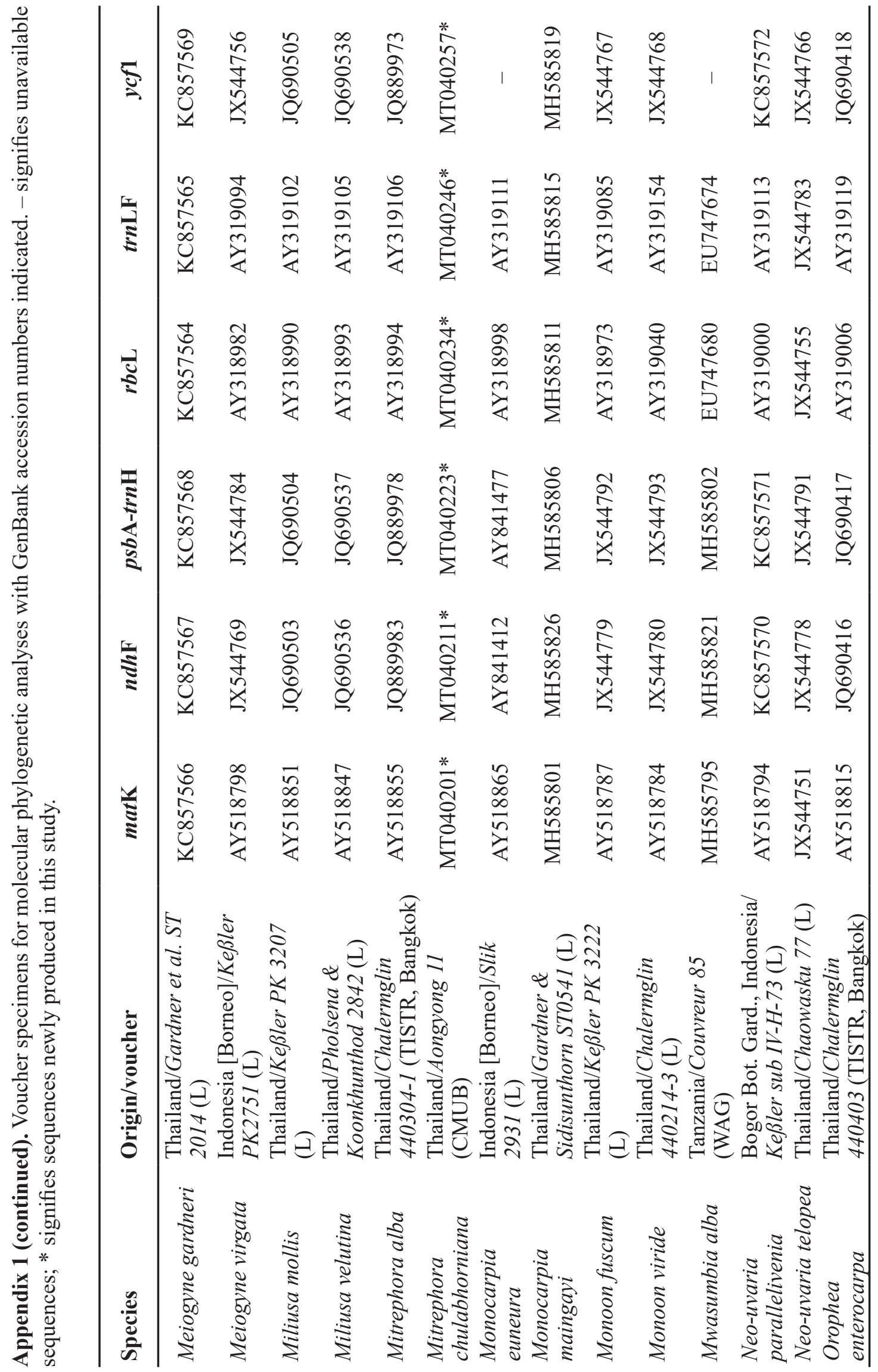




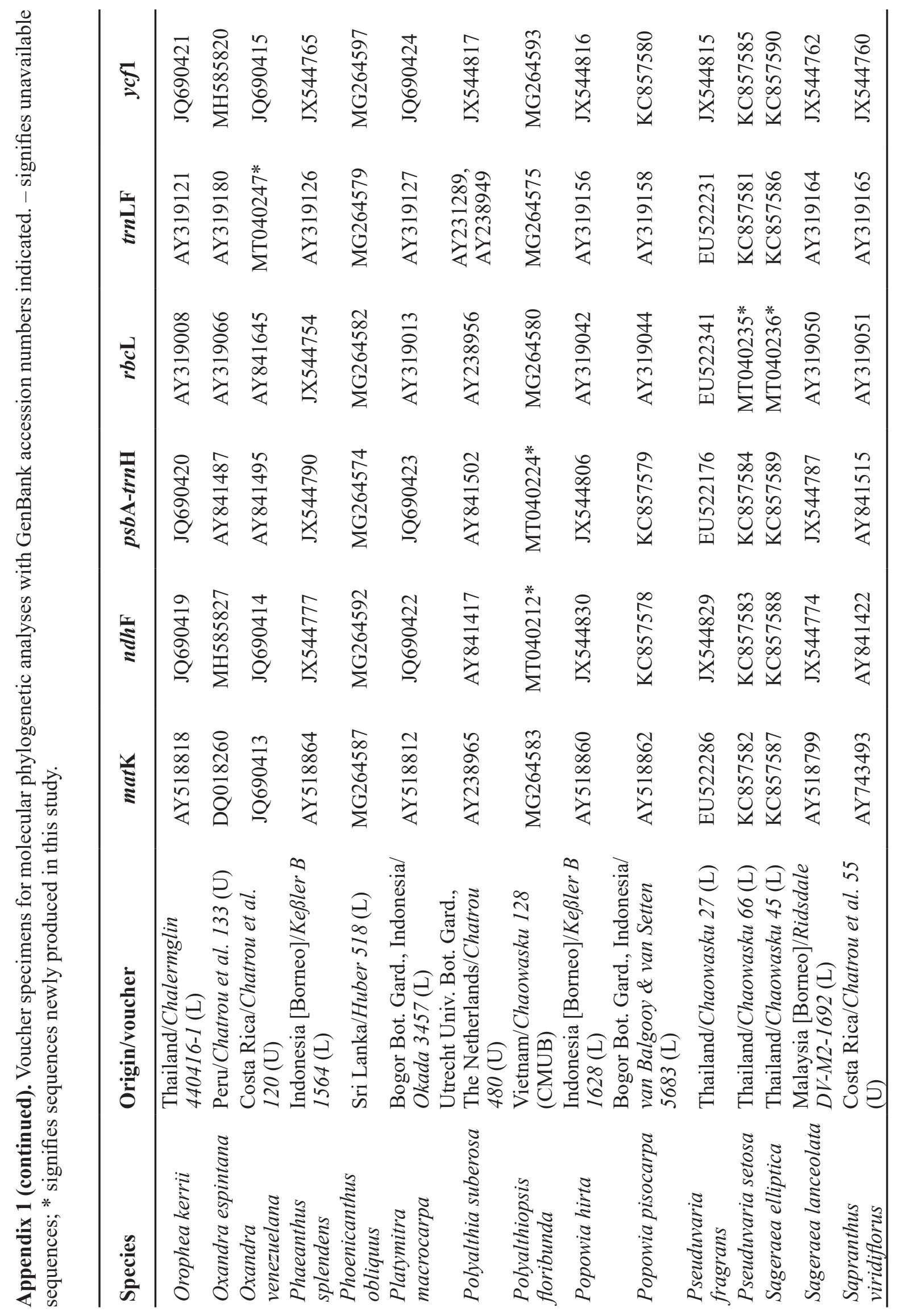




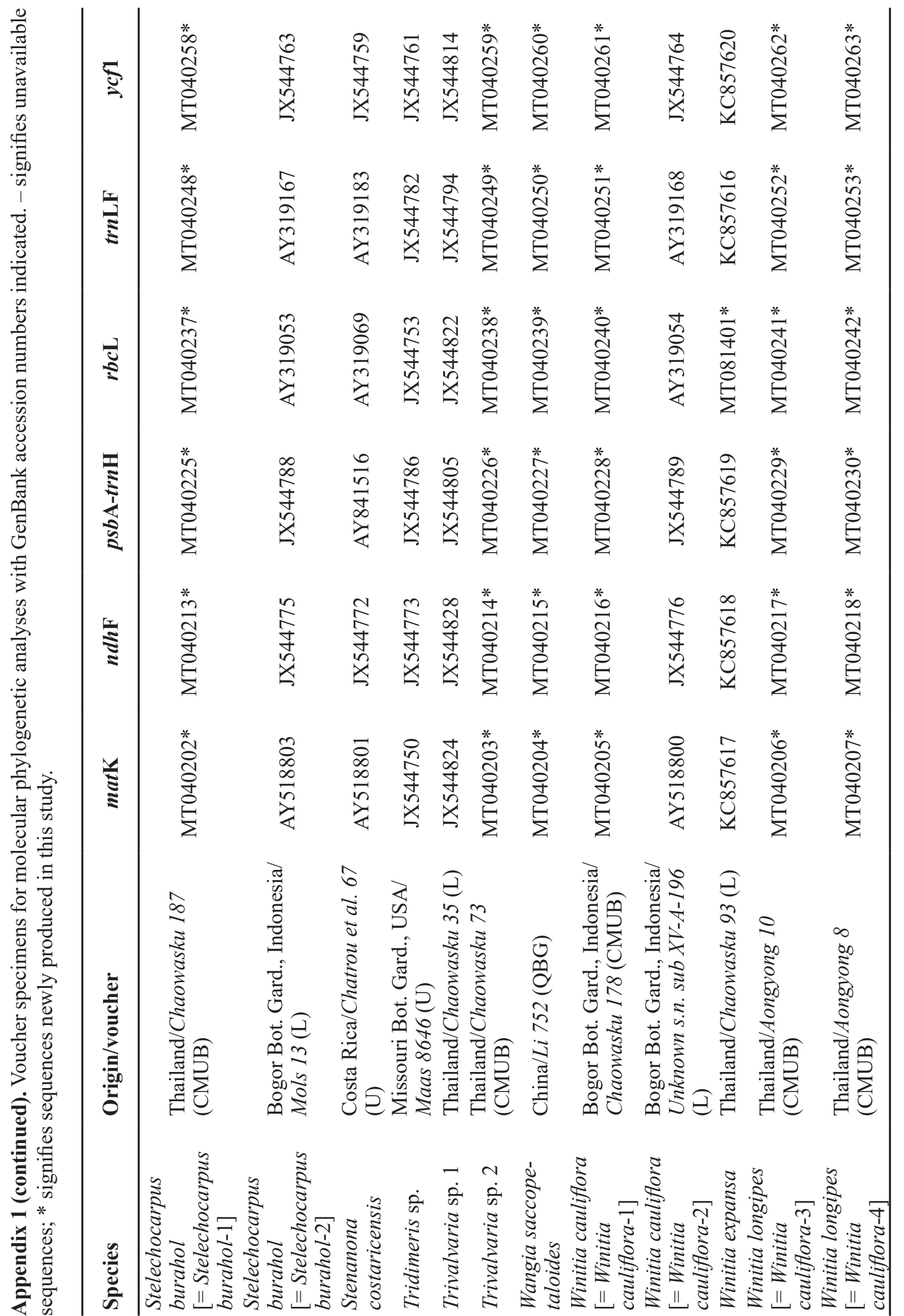




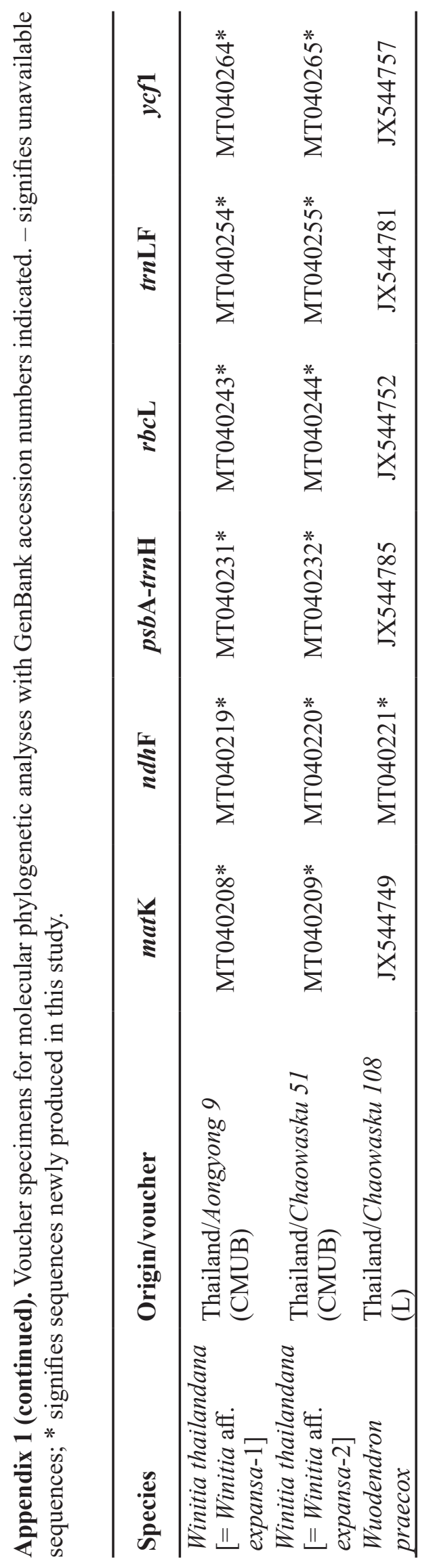


Appendix 2. Specimens morphologically examined in this study.

\begin{tabular}{llc}
\hline Species & Origin/voucher & Remarks \\
\hline Winitia cauliflora & Bogor Bot. Gard., Indonesia/Chaowasku 178 (CMUB) & X-F-96 \\
Winitia cauliflora & Bogor Bot. Gard., Indonesia/Chaowasku 185 (CMUB) & XV-A-196 \\
Winitia longipes & Thailand/Aongyong 8 (CMUB) & - \\
Winitia longipes & Thailand/Aongyong 10 (CMUB) & - \\
Winitia longipes & Thailand/Gardner et al. ST1665 (BKF, L) & Newly identified \\
Winitia longipes & Thailand/Plernchit 788 (BKF) & Newly identified \\
Winitia longipes & Thailand/Smitinand 2340 (BKF) & Newly identified \\
Winitia longipes & Thailand/van Beusekom \& Phengkhlai 1032 (BKF, L) & Newly identified \\
Winitia thailandana & Thailand/Aongyong 9 (CMUB) & Type specimens \\
Winitia thailandana & Thailand/Chaowasku 51 (CMUB) & \\
\hline
\end{tabular}

